\title{
Strategic framework to achieve carbon-efficient construction and maintenance of railway infrastructure systems
}

\author{
Sakdirat Kaewunruen ${ }^{1 *}$, Joseph M. Sussman ${ }^{2}$ and Herbert H. Einstein ${ }^{3}$ \\ ${ }^{1}$ Birmingham Centre for Railway Research and Education, School of Civil Engineering, University of Birmingham, Birmingham, UK \\ ${ }^{2}$ High Speed Rail Research Group, Department of Civil and Environmental Engineering, Massachusetts Institute of Technology, Cambridge, MA, USA \\ ${ }^{3}$ Department of Civil and Environmental Engineering, Massachusetts Institute of Technology, Cambridge, MA, USA \\ *Correspondence: sakdirat@hotmail.com; s.kaewunruen@bham.ac.uk
}

Edited by:

Ernesto Dos Santos Caetano Neto, National Autonomous University of Mexico, Mexico

Reviewed by:

Cholachat Rujikiatkamjorn, University of Wollongong, Australia

Makoto Ishida, Nippon Koei Co., Ltd., Japan

Keywords: carbon emissions, efficiency, construction and maintenance, railway infrastructure, strategic framework

\section{A commentary on}

Introducing a new limit states design concept to railway concrete sleepers: an Australian experience

Kaewunruen S., Remennikov A. M., and Murray M. H. (2014). Front. Mater. 1:8. doi: 10.3389/fmats.2014.00008

Rail transportation has evolved over a century to be relatively more efficient than ever (if not the most) around the world. Evidenced qualitatively and quantitatively, social and environmental benefits (combining reduced carbon emission, reduced congestion, reduced traffic mortality, improved urbanization and land uses, increased choices of lifestyle and job, new business capabilities and avenues, etc.) are significant positive outcomes from rail lines (Glaeser, 2009). Although railway transportation operation is one of the least contributors among other modes of transportation (i.e., aviation, cable, land, pipeline, waterway, or even space), the carbon emission from constructing and maintaining railway infrastructure systems is greater than those from other transport infrastructure systems. This is due to the fact that the railway infrastructure system is very complex by nature. It spans over large distance and contains comparatively many more supporting components and larger structural layers to cater safe, resilient and reliable services for either passengers or freights (Kaewunruen et al., 2014;
Krezo et al., 2014a, in press; Remennikov and Kaewunruen, 2014). In particular, the routine maintenance and renewal of aging components within the infrastructure are often required in order to assure safety and reliability of passengers and cargoes over the rail networks (Remennikov and Kaewunruen, 2008; Krezo et al., 2014b, in press).

Infrastructure renewal, construction, and maintenance activities are potentially responsible for over $20 \%$ of carbon dioxide $\left(\mathrm{CO}_{2}\right)$ emissions by overall railway functions as a whole, depending on the type of rail infrastructure system, rolling stock, electrification system, traffic operation, and surroundings such as geography and climate (Hill et al., 2011). In recent years, this result has prompted the industry need to systemically estimate and manage greenhouse gas emissions from railway construction and maintenance activities over life cycle. In general, there are two broad types of railway track infrastructure: ballasted and ballastless tracks. Ballasted track uses ballast (crushed aggregates) to support sleepers and rails whilst transferring the train loads to the substructure (Burrow et al., 2007; Indraratna et al., 2011). Ballastless track typically uses a concrete slab system to support the steel rails, which transfer the loads from passing trains to the concrete slab and foundation (Kiani et al., 2008). Within a rail infrastructure system, typical mainline components in plain tracks would experience considerably less wear and tear or damage when compared with special trackwork's components such as turnouts, diamonds, or crossovers. However, mainline railway track components deteriorate faster in tight curves, heavy axle loads, adverse weather conditions, and in a poor maintenance condition (Milford and Allwood, 2010). Simultaneously, supporting structures and facilities such as bridges, viaducts, stations, railway equipment, drainage system, electrification systems and so on also deteriorate overtime. As a result, the routine maintenance of railway infrastructure systems, which is an ongoing asset operation activity, is vital in ensuring reliability and longevity of infrastructure (Ueda et al., 2003; von Rozycki et al., 2003; Lee et al., 2008; Network Rail, 2009; Schwarz, 2009; Chang and Kendall, 2011; Krezo et al., in press).

Recent studies suggest that the carbon footprint due to ballasted track maintenance be comparable to that of concrete slab tracks over a 100 year life cycle. The data also exhibits that the emissions of embodied carbon of the materials used in ballasted and concrete slab track re-constructions contribute more than nine times the $\mathrm{CO}_{2}$ emissions from the diesel machineries used to maintain and re-construct the track beds (Krezo et al., in press). The track bed selection and the share of bridges and tunnels have the largest impact on the overall $\mathrm{CO}_{2}$ emissions. Thus, prolonging the re-construction frequency by optimal routine maintenance activities such as 
rail head grinding, defect removal, and resurfacing, is the key to reducing lifecycle $\mathrm{CO}_{2}$ emissions from overall maintenance over the whole lives of rail assets. Evidenced by a number of turnout renewal projects, it is also considered to be more financially- and carbon-efficient to carry out a bulk renewal (for multiple turnouts) in a single maintenance project than to work separately for each individual turnout (Schwarz, 2009; Chang and Kendall, 2011; Krezo et al., 2014b).

According to a recent review, a strategic framework for enabling carbon-efficient railway construction and maintenance

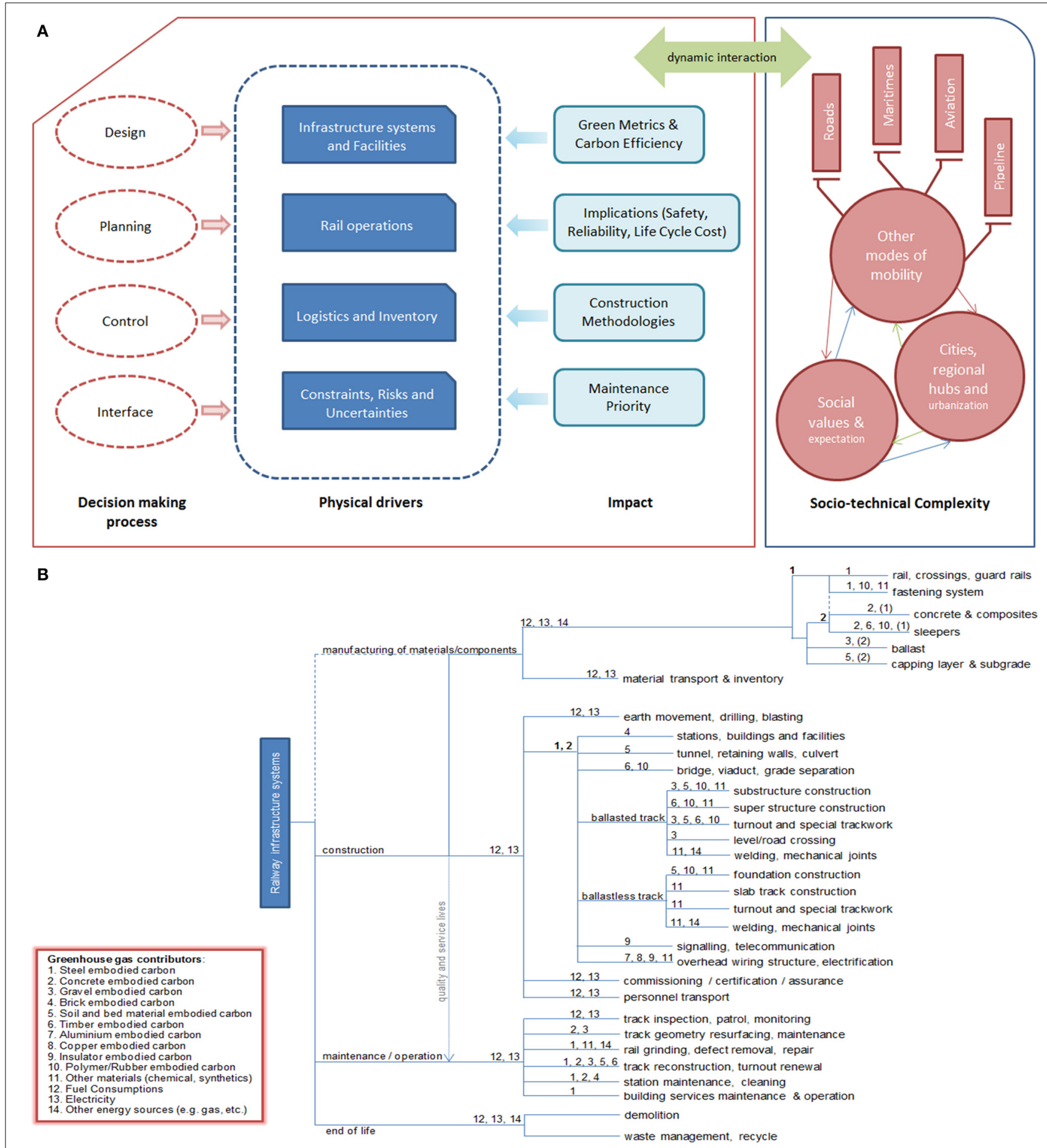

FIGURE 1 | (A) Strategic framework for carbon-efficient railway construction and maintenance. (B) Strategic cladogram for carbon-efficient railway infrastructure systems. 
can be illustrated in Figure 1A (Dekker et al., 2012; Kaewunruen et al., 2013). There are three main strategic criteria, which influence the carbon efficiency, including decision making process, physical drivers, and the impact. The impact from metrics, implications, methodologies and priority revolve around the decisionmaking processes and physical drivers. These multi criteria are also interconnected to socio-technical complexity, which drives the social expectation and value chains through to the shift from and the interaction with other transport modes.

It is likely that climate change and air pollution will become a major criterion in decision making in the next few decades (McKinnon, 2010). The management of railway construction and maintenance has moved from a simple event to a holistic systems-based approach. The carbon drivers in transports behave as a complex adaptive system and it evolves through the inter-connectivity and interaction. Using the evolutionary theory so-called phylogenetic analysis (Neil and Corrigan, 2013), a strategic decision tree, which provides a unique and powerful way of classifying carbon contributors, can be derived as demonstrated in Figure 1B. The technique can highlight a significant influence on the practical guideline for carbon efficiency. This can aid the effectiveness and efficiencies in strategically managing railway infrastructure construction and maintenance and practically allocating carbon-efficient resources, design concepts, or construction methodologies.

It is apparent in Figure 1B that when the appropriate contribution weight of greenhouse gas emission is adopted, practitioners can make strategic decisions to establish carbon-efficient railway infrastructure systems through the construction and maintenance activities. For instance, if the carbon emission by steel and concrete material manufacturing is relatively high in the urban region, the choice of materials, traffic operation and maintenance regime should be designed to prolong the service lives of infrastructure. In addition, with the help of phylogenetic analysis, the emerging carbon contributor can be identified. Accordingly, construction and maintenance managers can allocate appropriate resources and time to manage critical construction phases and materials to achieve financial, social and environmental gains. This would be a great attempt to help reducing carbon emission, which is the main contributor toward climate change that would later aggravate the performance and reliability of railway systems in a long run.

\section{ACKNOWLEDGMENTS}

This work was supported by Australian Government's Endeavour Executive Fellowship. The first author wishes to thank the Australian Government' Department of Innovation, Education, and Research for the Endeavour Executive Award, which financially supported his fellowships at Massachusetts Institute of Technology's Department of Civil and Environmental Engineering; Harvard University's John F. Kennedy School of Government; and Chalmers University of Technology's Centre for Railway Mechanics.

\section{REFERENCES}

Burrow, M. P. N., Bowness, D., and Ghataora, G. S. (2007). A comparison of railway track foundation design methods. Proc. Inst. Mech. Eng. 221, 1-12. doi: 10.1243/09544097JRRT58

Chang, B., and Kendall, A. (2011). Life cycle greenhouse gas assessment of infrastructure construction for California's high-speed rail system. Transp. Res. D. 16, 429-434. doi: 10.1016/j.trd.2011. 04.004

Dekker, R., Bloemhof, J., and Mallidis, I. (2012). Operations Research for green logistics - an overview of aspects, issues, contributions and challenges. Eur. J. Oper. Res. 219, 671-679. doi: 10.1016/j.ejor.2011.11.010

Glaeser, E. (2009, August 12). How big are the environmental benefits of high-speed rail? The New York Times. Available online at: http://www. hks.harvard.edu/centers/rappaport/events-and-ne ws/op-eds/how-big-are-the-environmental-benefi ts-of-high-speed-rail

Hill, N., Brannigan, C., Wynn, D., Milnes, R., van Essen, H., den Boer, E., et al. (2011). "The role of GHG emissions from infrastructure construction, vehicle manufacturing, and ELVs in overall transport sector emissions," in Task 2 Paper Produced as Part of a Contract Between European Commission Directorate-General Climate Action and AEA Technology plc. Available online at: www. eutransportghg2050.eu

Indraratna, B., Salim, W., and Rujikiatkamjorn, C. (2011). Advanced Rail Geotechnology Ballasted Track. London, UK: CRC Press/ Balkema.

Kaewunruen, S., Remennikov, A. M., Aikawa, A., and Sato, H. (2014). Free vibrations of interspersed railway track systems in three-dimensional space. Acoust. Aust. 14, 20-26.

Kaewunruen, S., Sussman, J., and Einstein, H. H. (2013). Working Paper - Transport Business Strategies for High Speed Rail Development in An Australian Context: A Review on Socio-Economic Values, Capability Framework, Lessons Learnt, Risk and Uncertainties. Unpublished Report for Endeavour Executive Fellowship, Sydney, NSW, Australia

Kiani, M., Parry, T., and Ceney, H. (2008). Environmental life-cycle assessment of railway track beds. Proc. Inst. Civ. Eng. Eng. Sustain. 161, 135-142. doi: 10.1680/ensu.2008. 161.2.135

Krezo, S., Mirza, O., He, Y., and Kaewunruen, S. (2014b). "Estimating carbon emissions from turnout, crossover and diamond renewal projects," in Engineers Australia Convention 2014: Practical Responses to Climate Change (Melbourne, VIC).

Krezo, S., Mirza, O., He, Y., Kaewunruen, S., and Sussman, J. M. (2014a). "Carbon emissions analysis of rail resurfacing work: a case study, practical guideline and systems thinking approach," in Proceedings of the Second International Conference on Railway Technology: Research, Development and Maintenance, ed J. Pombo (Stirlingshire: CivilComp Press), 288. doi: 10.4203/ccp.104.288

Krezo, S., Mirza, O., He, Y., Makim, P., and Kaewunruen, S. (in press). Estimating CO2 emissions from mainline railway reconstruction projects. Transp. Res. D.

Lee, C. K., Lee, J. Y., and Kim, Y.K. (2008) Comparison of environmental loads with rail track systems using simplified life cycle assessment (LCA). WIT Trans. Built Environ. 101, 367-372. doi: 10.2495/UT080361

McKinnon, A. (2010). Green logistics: the carbon agenda. Logforum 6, 1-9.

Milford, R., and Allwood, J. (2010). Assessing the $\mathrm{CO}_{2}$ impact of current and future track in the UK. Transp. Res. D 15, 61-72. doi: 10.1016/j.trd.2009.09.003

Neil, A., and Corrigan, J. (2013). "Emerging risk assessment - latest practice and innovations," The Actuaries Institute Summit (Sydney, NSW).

Network Rail. (2009). Comparing Environmental Impact of Conventional and High Speed Rail. London, UK: Department of Transport.

Remennikov, A. M., and Kaewunruen, S. (2008). A review of loading conditions for railway track structures due to train and track vertical interaction. Struct. Control Health Monit. 15, 207-234. doi: $10.1002 /$ stc. 227

Remennikov, A. M., and Kaewunruen, S. (2014). Experimental load rating of aged prestressed concrete sleepers. Eng. Struct. 76, 147-162. doi: 10.1016/j.engstruct.2014.06.032

Schwarz, H. (2009). Carbon Footprint of HighSpeed Railway Infrastructure (Pre-Study). Paris: International union of railways.

Ueda, H., Miyauchi, T., and Tsujimura, T. (2003). Application of lifecycle assessment to Shinkansen vehicles and cross ties in Japan. Proc. Inst. Mech. Eng. J. Rail Rapid Transit. 217, 271-278. doi: 10.1243/0954409033227 12874 
von Rozycki, C., Koeser, H., and Schwarz, H. (2003). Ecology profile of the German high-speed rail passenger transport system, ICE. Int. J. Life Cycle Assess. 8, 83-91. doi: 10.1007/BF02978431

Conflict of Interest Statement: The authors declare that the research was conducted in the absence of any commercial or financial relationships that could be construed as a potential conflict of interest.
Received: 24 October 2014; accepted: 21 January 2015; published online: 10 February 2015.

Citation: Kaewunruen S, Sussman JM and Einstein HH (2015) Strategic framework to achieve carbon-efficient construction and maintenance of railway infrastructure systems. Front. Environ. Sci. 3:6. doi: 10.3389/fenvs. 2015.00006

This article was submitted to Interdisciplinary Climate Studies, a section of the journal Frontiers in Environmental Science.
Copyright (C) 2015 Kaewunruen, Sussman and Einstein. This is an open-access article distributed under the terms of the Creative Commons Attribution License (CC BY). The use, distribution or reproduction in other forums is permitted, provided the original author(s) or licensor are credited and that the original publication in this journal is cited, in accordance with accepted academic practice. No use, distribution or reproduction is permitted which does not comply with these terms. 